\title{
Karyotypic analysis in species of the genus Dasyprocta (Rodentia: Dasyproctidae) found in Brazilian Amazon
}

\author{
ROSEMAR S. L. RAMOS ${ }^{1}$, WILLIAM G. VALE ${ }^{1}$ and FÁTIMA L. ASSIS ${ }^{2}$ \\ ${ }^{1}$ Department of Biology - CCB - UFPA, 66073-290 Belém, Pará, Brasil. \\ ${ }^{2}$ Department of Genetics - CCB - UFPA \\ Manuscript received on October 26, 2001; accepted for publication on December 11, 2002; \\ presented by LEWIS J. GREENE
}

\begin{abstract}
A total of 30 animals of the genus Dasyprocta were cytogenetically studied. They belong to the following species: D. prymnolopha $(\mathrm{N}=20)$, D. leporina $(\mathrm{N}=6)$, D. fuliginosa $(\mathrm{N}=1)$ and Dasyprocta $\mathrm{sp}$. $(\mathrm{N}=3)$ (Dasyproctidae, Hystricognathi). Cell suspensions were obtained by peripheral blood culture, besides bone marrow and spleen cells, from D. prymnolopha and D. leporina. The diploid number was 64/65 for all samples. The karyotypes showed similarity, and chromosomal polymorphism was not detected by Giemsa conventional staining and $\mathrm{G}$ banding. The constitutive heterochromatin distribution at the pericentromeric region of all the chromosomes was similar in all species. D. prymnolopha, D. leporina and Dasyprocta sp. presented variation in the heterochromatical block size at one of the homologues of the A18 pair. $D$. fuliginosa presented the heterochromatin uniformly distributed in all chromosomes. There was not variation in the NORs pattern in the species studied.
\end{abstract}

Key words: Cytogenetics, Hystricognathi, Dasyprocta, Karyotype.

\section{INTRODUCTION}

The Dasyprocta (Hystricognathi) genus includes about 11 species and 33 subspecies, and occurs from the south Mexico as far as high Amazon, including the Antilles, Colombia and Peru (Eisenberg 1989, Emmons 1990). Some forms are not easily recognizable due to taxonomic problems, and absence of any modern taxonomic revision (Emmons 1990).

Cytogenetic data in this genus are scanty. From eleven accepted species, only three (D. leporina, D. fuliginosa and $D$. variegata) have their karyotypes studied, presenting $2 \mathrm{n}=64$ chromosomes with conventional staining (Hungerford and Snyder 1964, Fredga 1966, Hsu and Benirschke 1968, Kasahara

Correspondence to: Rosemar Silva Luz Ramos

E-mail: rozita@bol.com.br and Yonenaga-Yassuda 1984). Lima (1993) studied D. leporina and D. fuliginosa species through $\mathrm{G}$ and $\mathrm{C}$ banding standards and through Nucleolus Organizer Regions (NORs). Both species present well-defined constitutive heterochromatin located in the pericentromeric region of all the autosome chromosomes, with variable intensity. The $\mathrm{X}$ chromosome presents pericentromeric $\mathrm{C}$ banding and the $\mathrm{Y}$ chromosome of $\mathrm{D}$. leporina is almost totally heterochromatic. In both species, the Ag-NOR is located in the telomeric region of only one acrocentric pair.

Therefore, the presented research has the proposal of characterize karyotypes of $D$. leporina, $D$. prymnolopha, D. fuliginosa and Dasyprocta sp. in specimens from the Brazilian Amazon, using $G$ (GTG) and C (CBG) bandings and NOR techniques 
TABLE I

Species and number of animals specified by sex, using preparations obtained with different tissues.

\begin{tabular}{l|l|l|l}
\hline Species & Peripheral blood & Bone Marrow & Spleen \\
\hline D. prymnolopha & $20(9 \mathrm{~F}$ and $11 \mathrm{M})$ & $6(1 \mathrm{~F}$ and $5 \mathrm{M})$ & $3 \mathrm{M}$ \\
\hline D. leporina & $6(2 \mathrm{~F}$ and $4 \mathrm{M})$ & $2(1 \mathrm{~F}$ and $1 \mathrm{M})$ & $2(1 \mathrm{~F}$ and $1 \mathrm{M})$ \\
\hline D. fuliginosa & $1 \mathrm{~F}$ & & \\
\hline Dasyprocta $\mathrm{sp}$. & $3(1 \mathrm{~F}$ and $2 \mathrm{M})$ & & \\
\hline Total & 30 & 8 & 5 \\
\hline
\end{tabular}

$\mathrm{F}=$ female $\mathbf{M}=$ male

to verify chromosomal polymorphism.

\section{MATERIALS AND METHODS}

Twenty specimens of D. prymnolopha, six of $D$. leporina, one of $D$. fuliginosa and three of Dasyprocta sp. were cytogenetically analyzed. These specimens were maintained at the vivarium of the Federal University of Pará (UFPA) and Museu Paraense Emílio Goeldi Zoobotanic Park. The progeny from couples kept in the vivarium of the UFPA are included in this sample. Most of these animals are from unknown origin, including those from MPEG. All the animals were subjected to peripheral blood collection: eight to bone marrow and five to spleen.

Table I shows species, number and genus of animals analyzed by peripheral blood, bone marrow and spleen. To obtain metaphasic chromosomes from lymphocytes culture, the modified methodology described by Moorhead et al. (1960) was used, where the mitogenic agent utilized was the Pokeweed. To obtain chromosomes from bone marrow, the methodology described by Baker et al. (1982) with modifications was used.

\section{Live Animals}

The animals were sedated with Ketalar (ParkeDavis \& Co., Aché Laboratórios Farmacêuticos S.A. Brasil) and Rompum (Bayer do Brasil S.A. Veterinária, Brasil) by intramuscular way in proportions of 0.3 and $0.1 \mathrm{ml} / \mathrm{kg}$ of body weight, respectively. The bone marrow cells collection was done in the region of femur-tíbio-patelar joint with syringe and $\mathrm{BD}$ (Luerlok) $30 \times 12$ special needle with mandril. The collected material was transferred to the centrifuge's tube that contained $5 \mathrm{ml}$ of medium HAMF10, added of $20 \%$ of foetal serum and $0,025 \mathrm{ml}$ of colchicine at $0.02 \%$ being incubated at $37^{\circ} \mathrm{C}$ during 40-60 minutes.

\section{SACRIFICED ANIMALS}

The animals were sacrificed with an excess dosis of Ketalar and Rompum associated with ether or chloroform inhalation. Four hours before the sacrifice, a proportion of $1 \mathrm{ml}$ to $1000 \mathrm{~g}$ of the body weight of colchicine at $0.02 \%$ was injected by intramuscular way. In addition to the bone marrow cells collected, the spleen was removed. To obtain metaphasic cells from spleen, the technique described by Ford and Hamerton (1956) was used. To obtain the G and C banding and NOR the methodologies described by Seabright (1971), Sumner (1972) and Howell and Black (1980) were used. The karyotypes were set up in decreasing size order in according to Hungerford and Snyder (1964) model.

\section{RESULTS}

All analyzed specimens presented a diploid number of 64/65 chromosomes (Figures 1A to 3B). This variation was observed with a frequency of about 


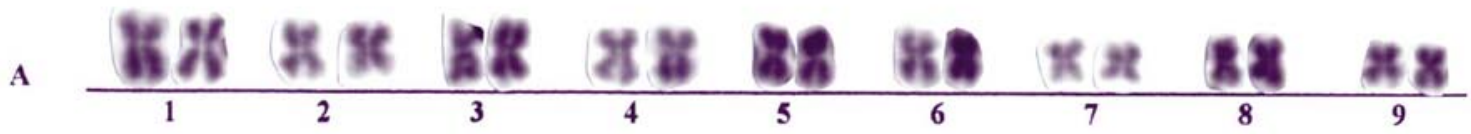
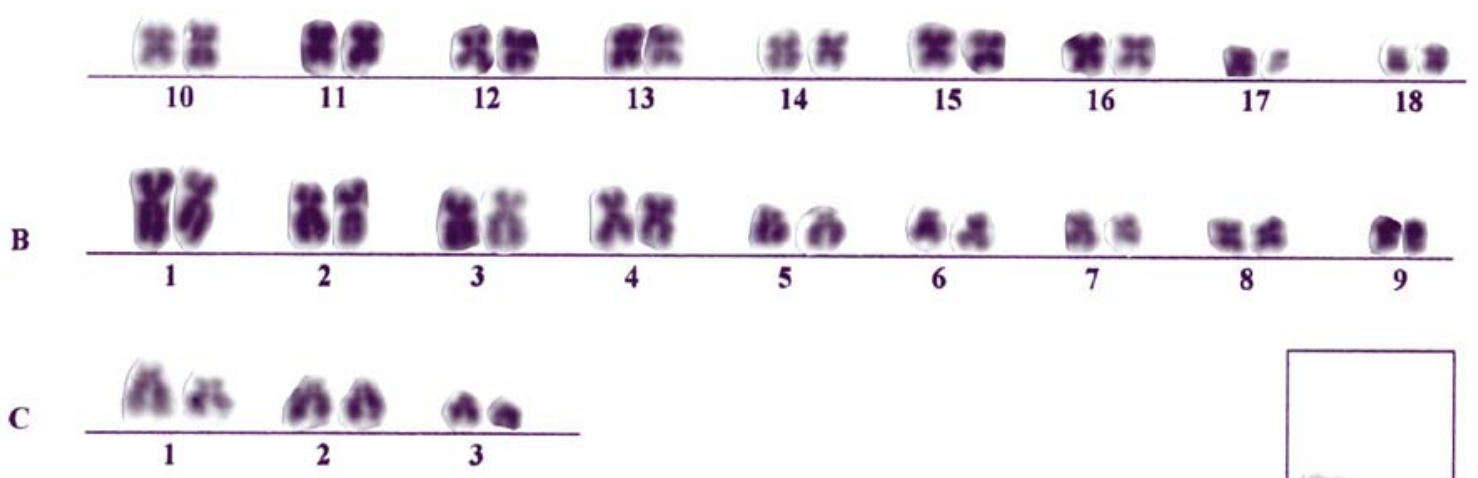

D $\frac{(8) 6}{1}$

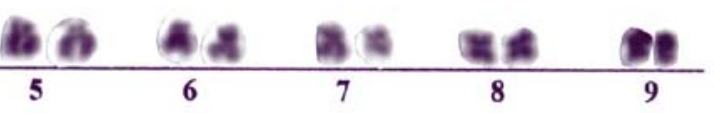

A
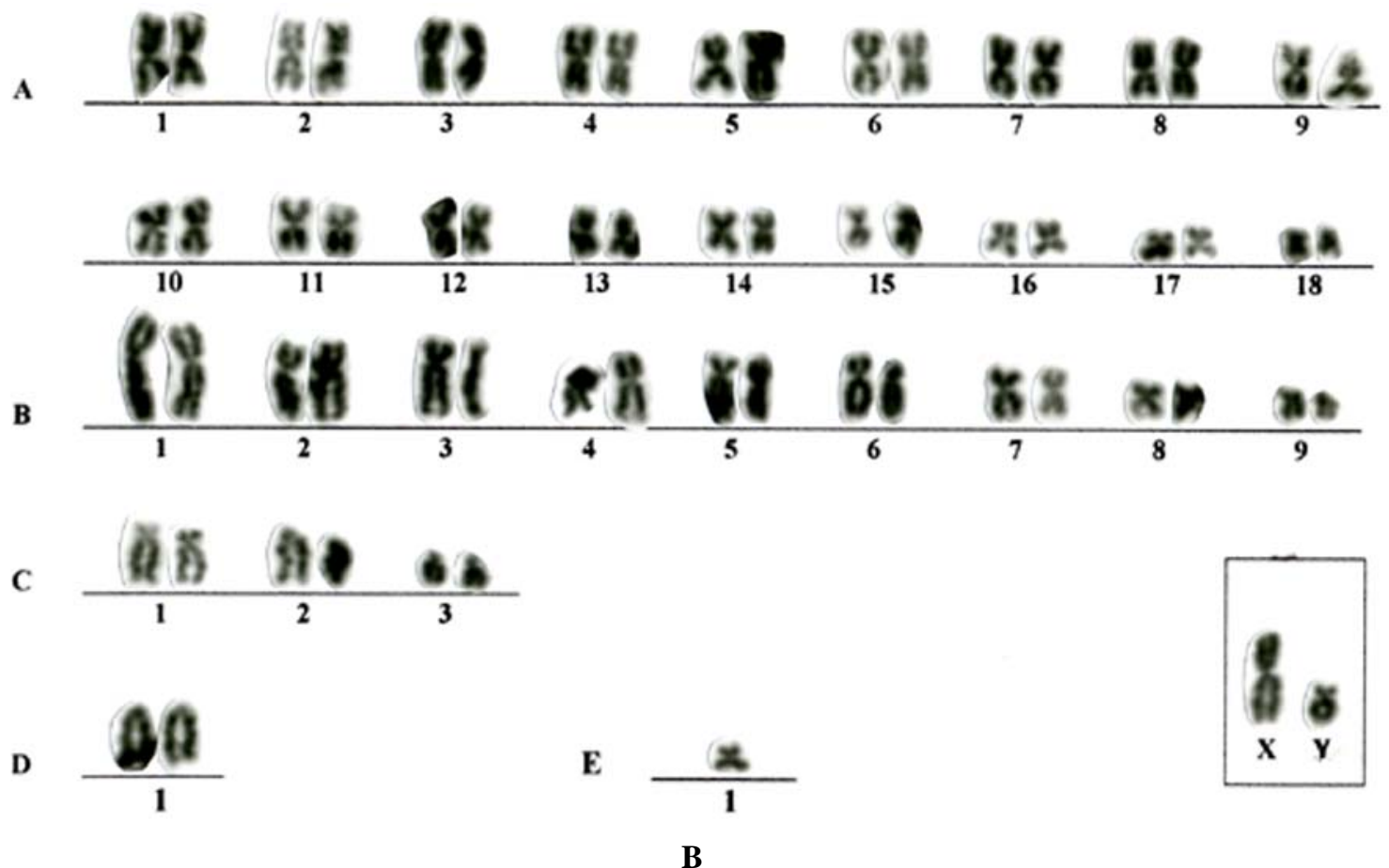

B

Fig. 1 - Karyotypes of the lineages $2 \mathrm{n}=64$ and $2 \mathrm{n}=65$ (lymphocytes culture) from the male sample $(\mathrm{N}=277$ ) of D. prymnolopha in conventional Giemsa stain. A) lineage $2 \mathrm{n}=64$; B) lineage $2 \mathrm{n}=65$. 
$70 \%$ in cells with $2 n=64$ and $30 \%$ in cells with $2 n=65$, in the three different tissues: peripheral blood in all species; bone marrow and spleen in D. prymnolopha and D. leporina (Tables II, III and IV). The lineage $2 n=65$ presents a supernumerary metacentric chromosome with size ranging between medium and small (Figures 1B, 2B and 3B) in D. prymnolopha, D. leporina and Dasyprocta sp., whereas in D. fuliginosa it seems to be a submetacentric (Figure 4). Through the conventional Giemsa stain, the chromosomes of the lot $\mathrm{A}(2 n=$ 64) showed the same morphology in all studied species. The karyotypes were characterized by the following model:

Group A - 18 pairs of metacentric chromosomes being the A1 pair the largest metacentric and the A18 pair, the smallest, with other pairs varying in size from large to small. The A18 pair presents, in the short arm, a morphology similar to a lower degree of spiralization looking like a secondary constriction, in conventional stain (Figure 2A).

Group B - nine pairs of submetacentric chromosomes, ranging from large to small.

Group $\mathrm{C}$ - three pairs of subtelocentric ones, pairs $\mathrm{C} 1$ and $\mathrm{C} 2$ of medium size, and $\mathrm{C} 3$ pair with small size.

Group D - only one acrocentric pair with large size.

$\mathrm{X}$ Chromosome - submetacentric with large size.

Y Chromosome - small submetacentric, smaller than the B9 pair. This chromosome was observed in D. prymnolopha, D. leporina and Dasyprocta sp.; however only one female of $D$. fuliginosa was karyotyped.

$\mathrm{G}$ band pattern was similar in all analyzed samples (Figure 4). C banding technique allows the identification in all species, in the different analyzed tissues, of constitutive heterochromatin in the pericentromeric region of the most of the autosomes, including the supernumerary chromosomes (Figure $5 \mathrm{~A})$.

In the $\mathrm{X}$ chromosome, the constitutive heterochromatin was restricted to pericentromeric re- gion, whereas in the $\mathrm{Y}$ chromosome, was observed variation in the distribution of this chromatin. In the D. prymnolopha the constitutive heterochromatin was limited to pericentromeric region (Figure 5). In D. leporina and Dasyprocta sp., the Y chromosome was almost totally heterochromatic (Figures 5B and C). The A6 pair in D. prymnolopha, D. leporina and Dasyprocta sp. presented polymorphism in the amount of constitutive heterochromatin. One of the chromosomes showed the heterochromatic block twice the size of the other homologous of the pair (Figures 5A, B and C). In D. fuliginosa karyotype no polymorphism was observed (Figure 6 ). The A18 pair in D. prymnolopha and Dasyprocta sp. karyotypes showed constitutive heterochromatin in only one of the homologues (Figures 5A and C). This pair, in the D. leporina and D. fuliginosa karyotypes did not show variation (Figures 5B and 6). D. fuliginosa karyotype showed uniformity in the standard distribution of constitutive heterochromatin in all of chromosomes (Figure 6).

The NORs were observed in the telomeric region of D1 acrocentric pair short arm, in the karyotypes obtained using different tissues of all specimens studied (Figure 7).

\section{DISCUSSION}

All specimens of D. prymnolopha, D. leporina, Dasyprocta sp. and $D$. fuliginosa presented two cellular lineages, with $2 n=64$ and $2 n=65$ chromosomes. No animal showed only the basic karyotype of $2 n=64$, as described in the literature (Kasahara and Yonenaga-Yassuda 1984, Lima 1993, Lima and Langguth 1995, 1998). This variation is because of the presence of one supernumerary chromosome metacentric in the D. prymnolopha, D. leporina and Dasyprocta sp. and submetacentric in D. fuliginosa. Supernumerary chromosomes are considered common among the Hystricognathi, mainly in the Chinchillidae, Octodontidae, Caviidae, Ctenomyidae, Hydrochaeridae and Echimyidae (George and Weir 1974, Kasahara and Yonenaga-Yassuda 1984, Leal-Mesquita 1991a, b, 
A
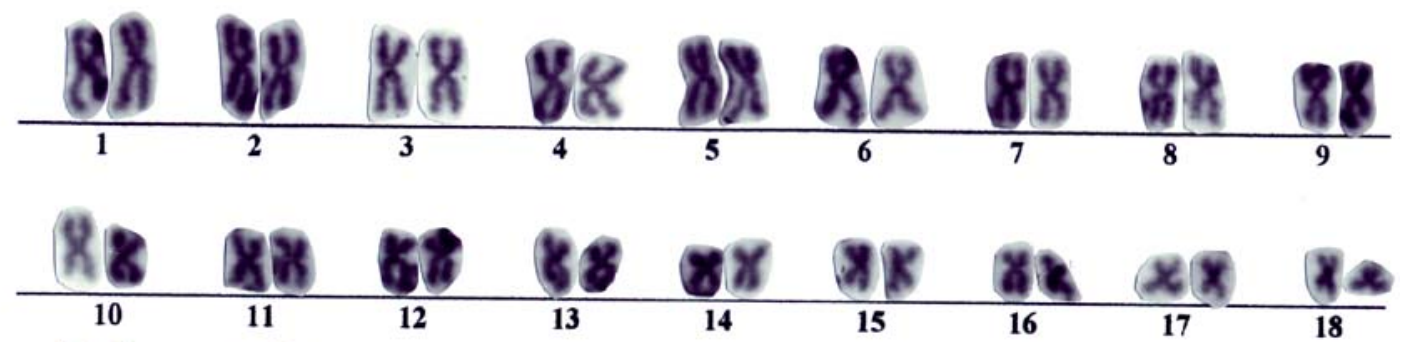

B

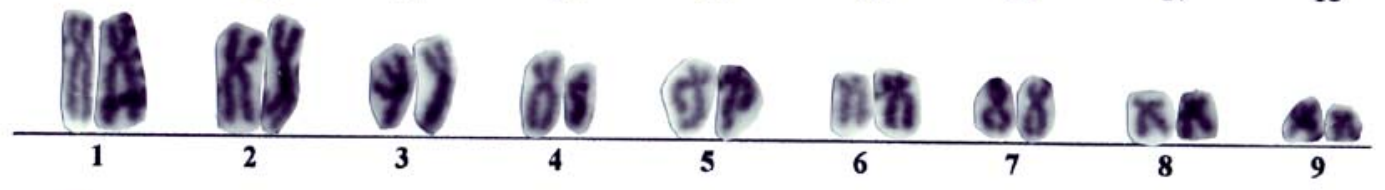

C

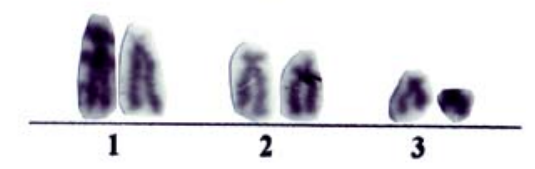

D $\frac{819}{1}$

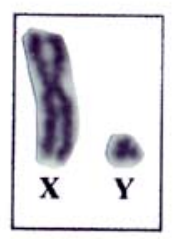

A
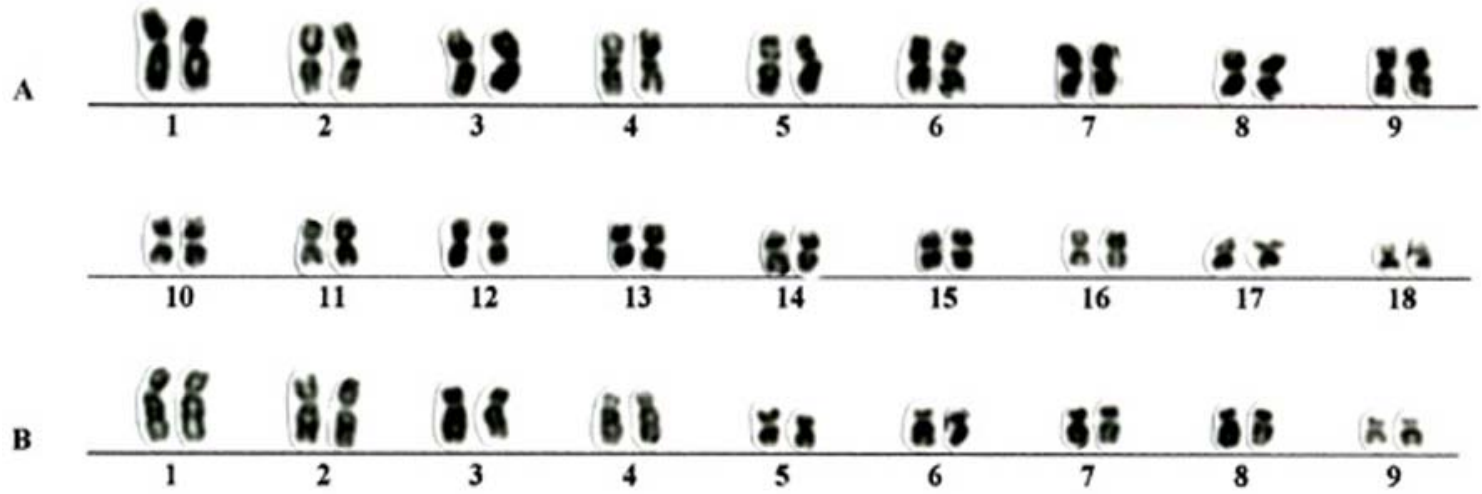

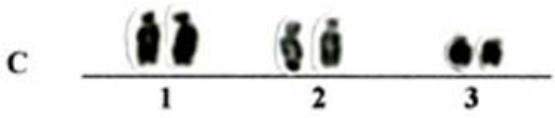

D $\frac{08}{1}$
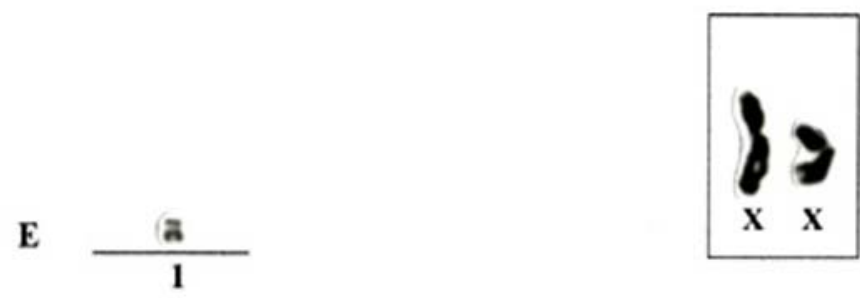

B

Fig. 2 - Karyotype of the lineage $2 n=64$ (marrow bone) and $2 n=65$ (lymphocytes culture) of D. leporina in conventional Giemsa stain. A) lineage $2 n=64$ from a male; B) lineage $2 n=65$ from a female. 

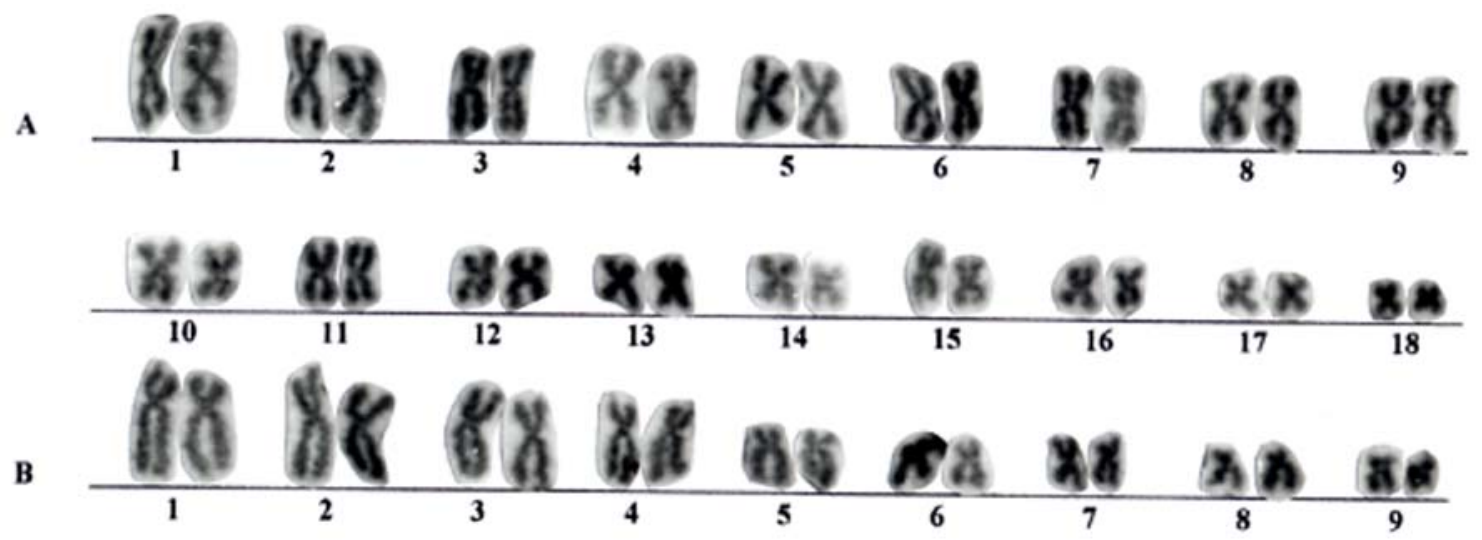

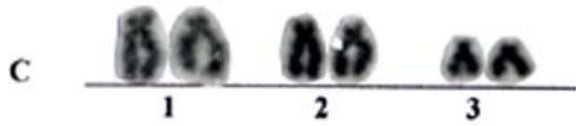

D $\frac{k \neq 1}{1}$

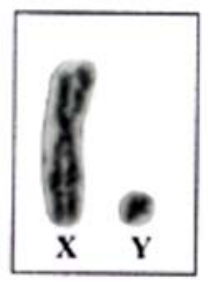

A
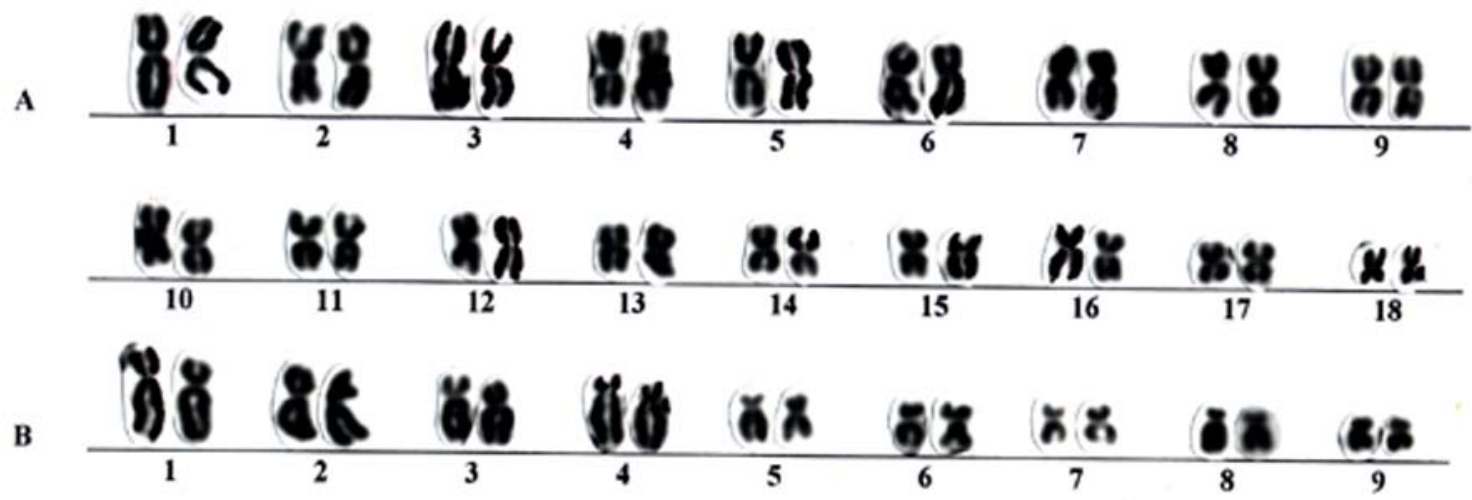

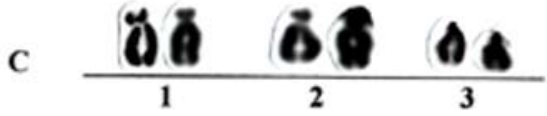

D $\frac{\text { o }}{1}$
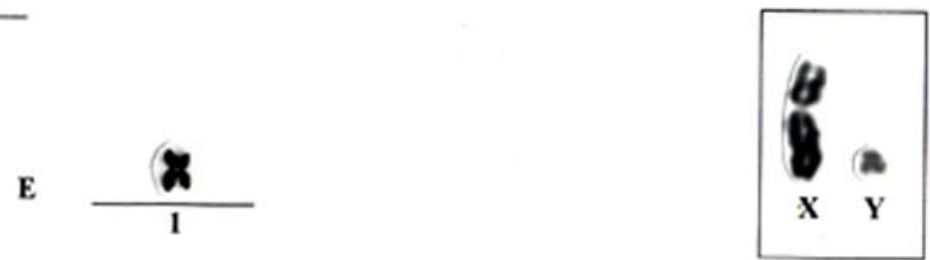

B

Fig. 3 - Karyotypes of the lineages $2 \mathrm{n}=64$ and $2 \mathrm{n}=65$ (lymphocytes culture) from a male sample (N=283) of Dasyprocta sp. in conventional Giemsa stain. A) lineage $2 n=64$; B) lineage $2 n=65$. 


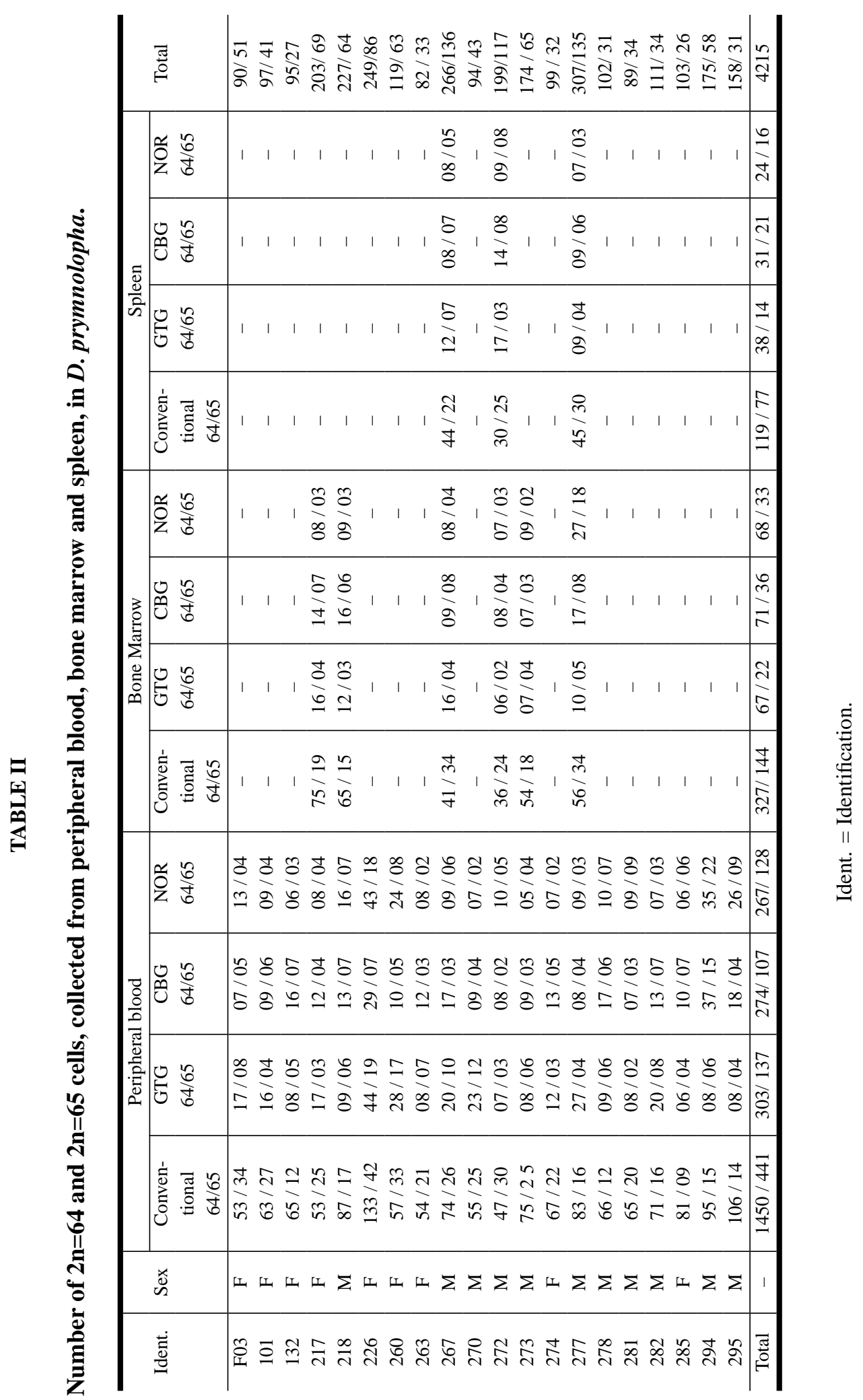




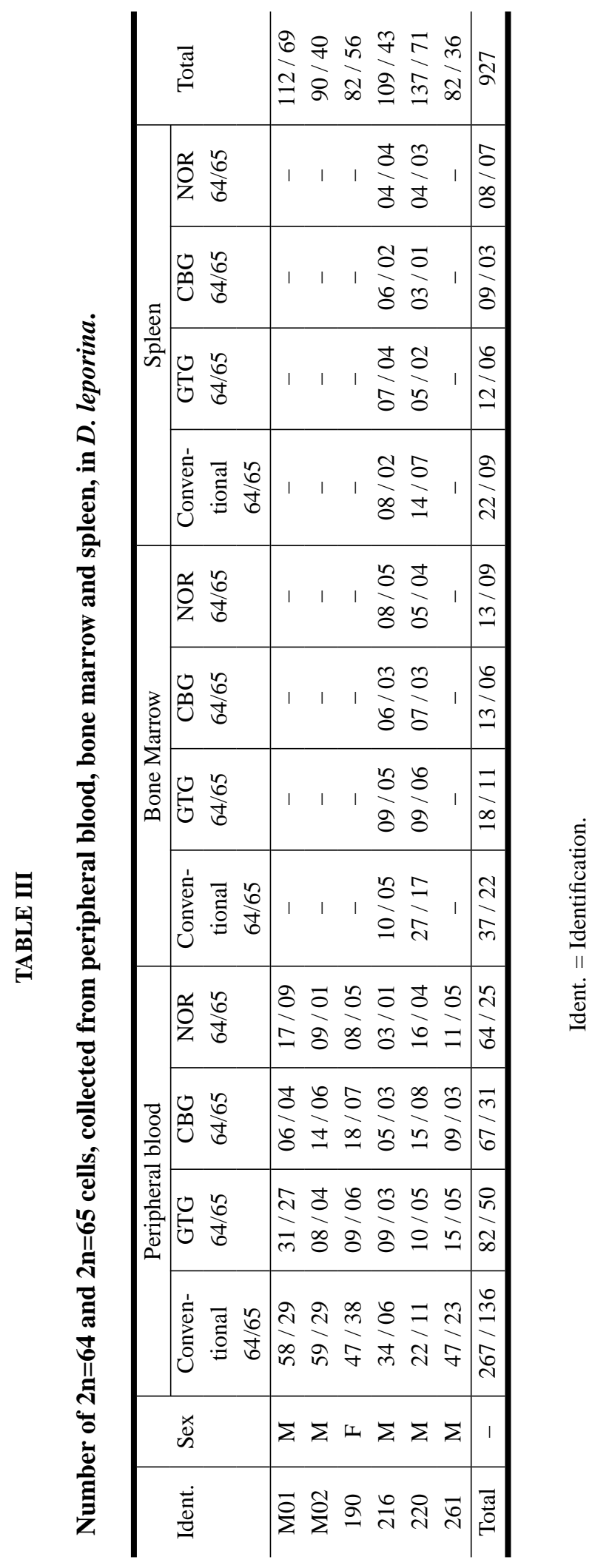


A
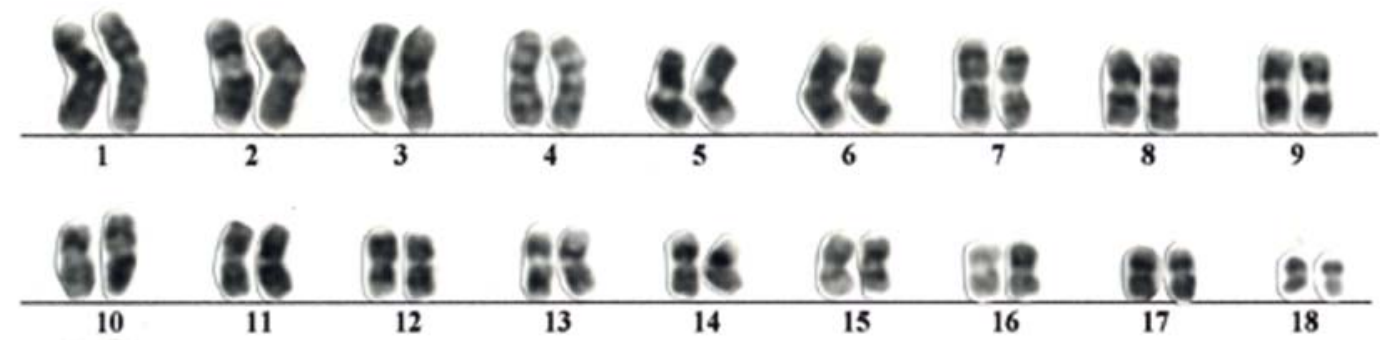

B

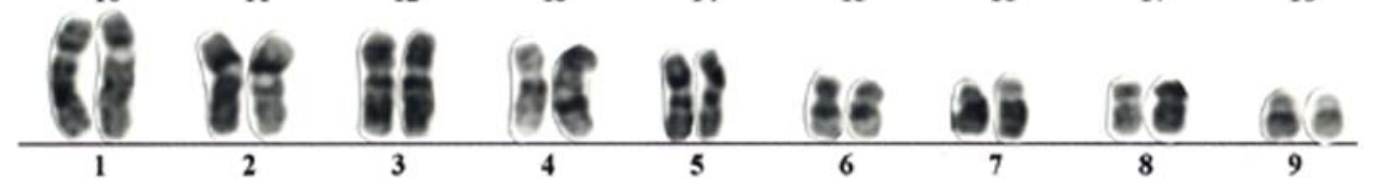

C
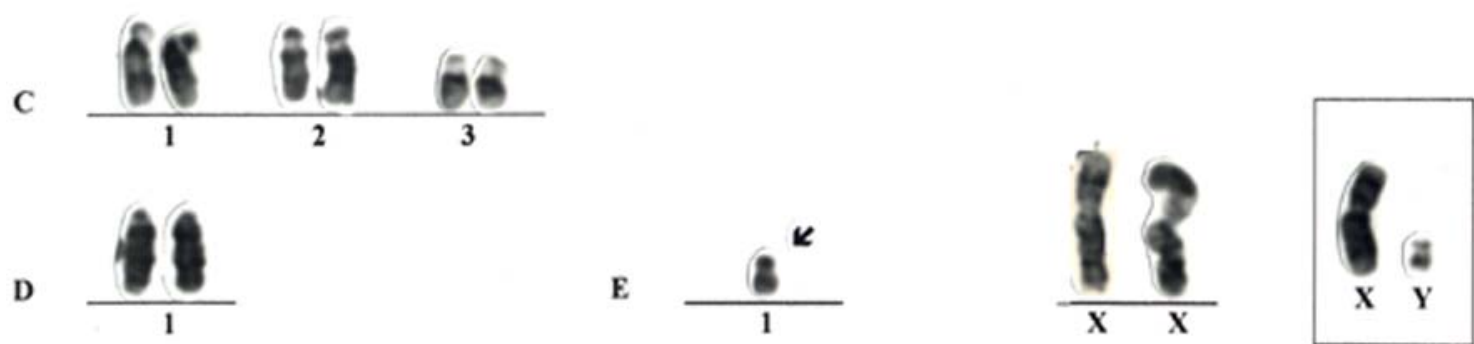

Fig. 4 - Banding G (GTG) standard of the lineage $2 \mathrm{n}=65$ from a female sample of $D$. fuliginos $a$. The arrow points to the banded supernumerary chromosome. Standing out, it appears the sexual pair: $\mathrm{X}$ and $\mathrm{Y}$ chromosomes, from a male of D. prymnolopha.

TABLE IV

Number of $2 n=64$ and $2 n=65$ cells, collected from peripheral blood, bone marrow and spleen, in Dasyprocta sp. and peripheral blood, in D. fuliginosa.

\begin{tabular}{|c|c|c|c|c|c|c|c|}
\hline \multirow[b]{2}{*}{ Species } & & \multicolumn{5}{|c|}{ Staining and Banding } & \multirow[b]{2}{*}{ Total } \\
\hline & & Sex & $\begin{array}{c}\text { Conven- } \\
\text { tional } \\
64 / 65\end{array}$ & $\begin{array}{l}\text { GTG } \\
64 / 65\end{array}$ & $\begin{array}{l}\text { CBG } \\
64 / 65\end{array}$ & $\begin{array}{l}\text { NOR } \\
64 / 65\end{array}$ & \\
\hline \multirow{3}{*}{ D.sp. } & 01 & $\mathrm{~F}$ & $63 / 17$ & $10 / 08$ & $13 / 10$ & $12 / 09$ & $98 / 44$ \\
\hline & 283 & M & $84 / 08$ & $32 / 13$ & $09 / 06$ & $08 / 04$ & $133 / 31$ \\
\hline & 284 & M & $79 / 16$ & $32 / 27$ & $20 / 10$ & $15 / 05$ & $146 / 58$ \\
\hline Total & & & $226 / 41$ & $74 / 48$ & $42 / 26$ & $35 / 18$ & 510 \\
\hline D.fulig. & 53 & $\mathrm{~F}$ & $74 / 21$ & $43 / 17$ & $15 / 06$ & $17 / 07$ & $149 / 51$ \\
\hline
\end{tabular}

D. sp. = Dasyprocta sp.; D. fulig. $=$ D. fuliginosa

Gallardo 1991, 1992, Fagundes and Yassuda 1995, Moreira et al. 1995). The presence of lineage $2 n=$ 65 , with one supernumerary chromosome in our sample, can characterize a geographic variation, since all constants species of literature were derived from different South America regions other than the Northern region.

In D. prymnolopha, D. leporina and D. fuliginosa we detected a small variation in the A18 pair in relation to Dasyprocta sp. due to the fact that $100 \%$ 
A
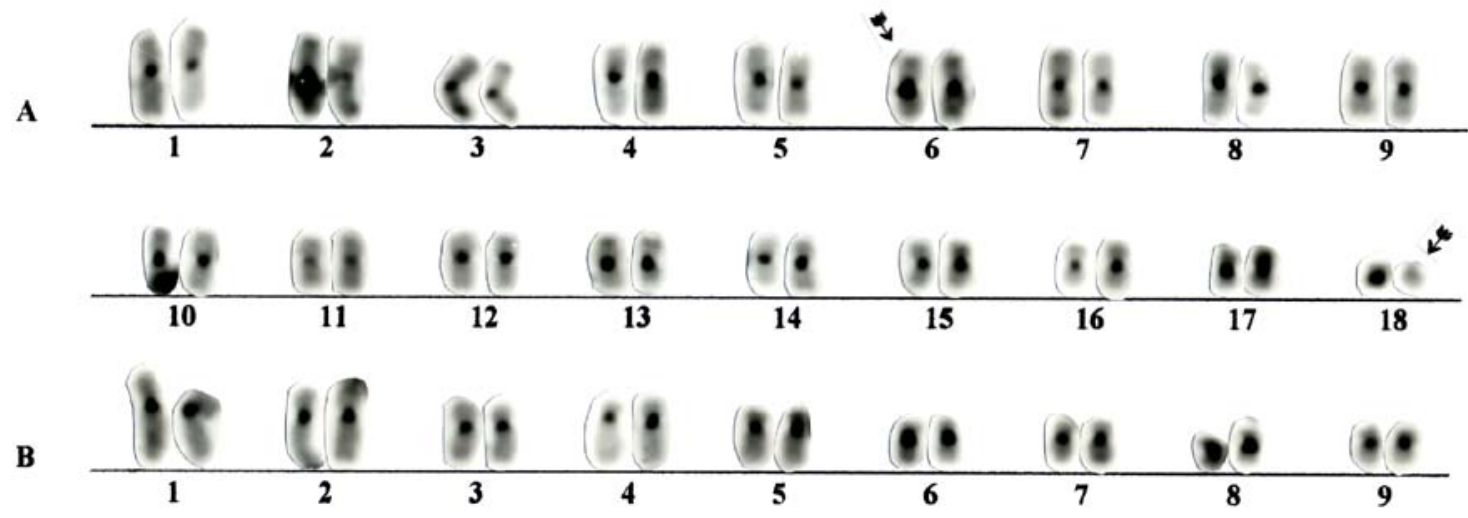

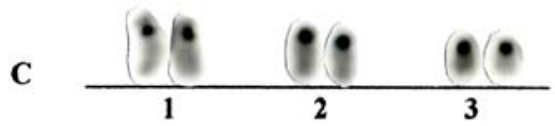
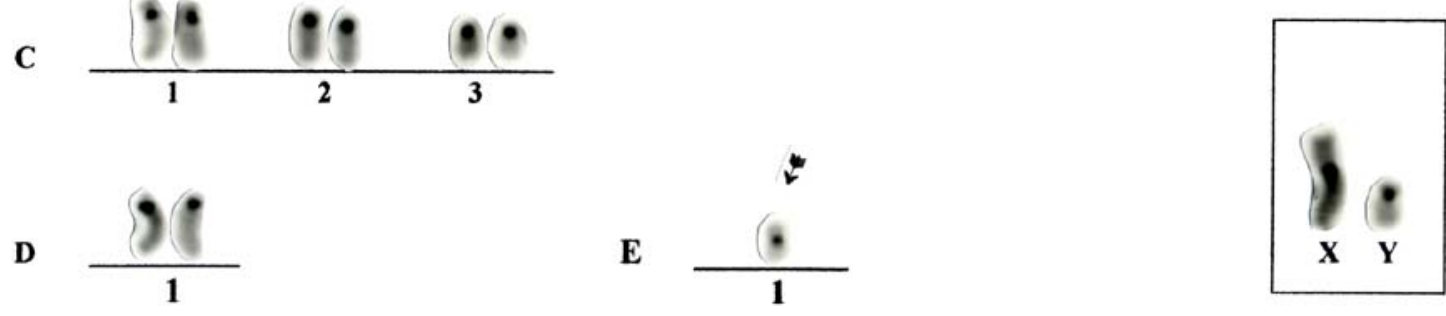

Fig. 5A

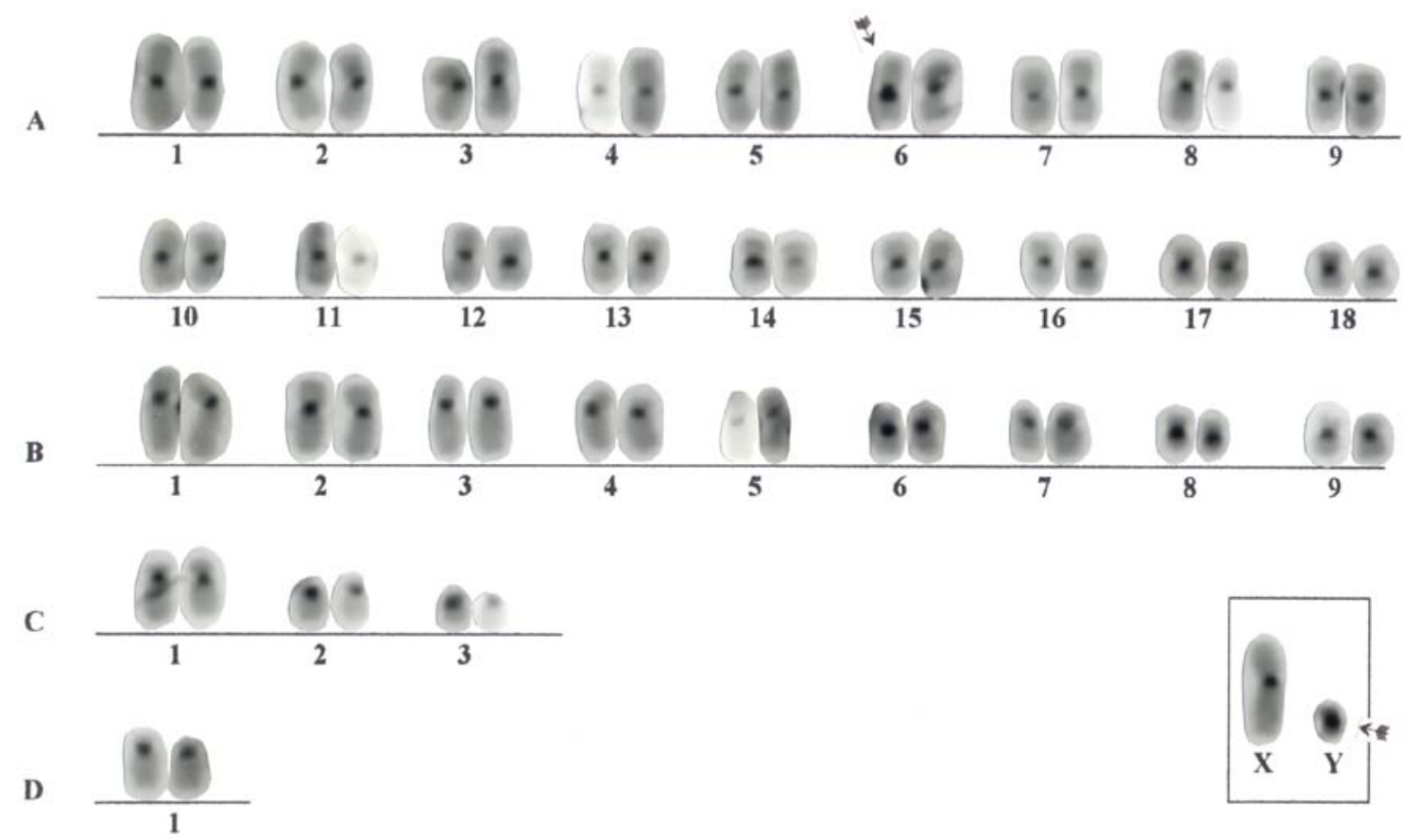

Fig. 5B 
A
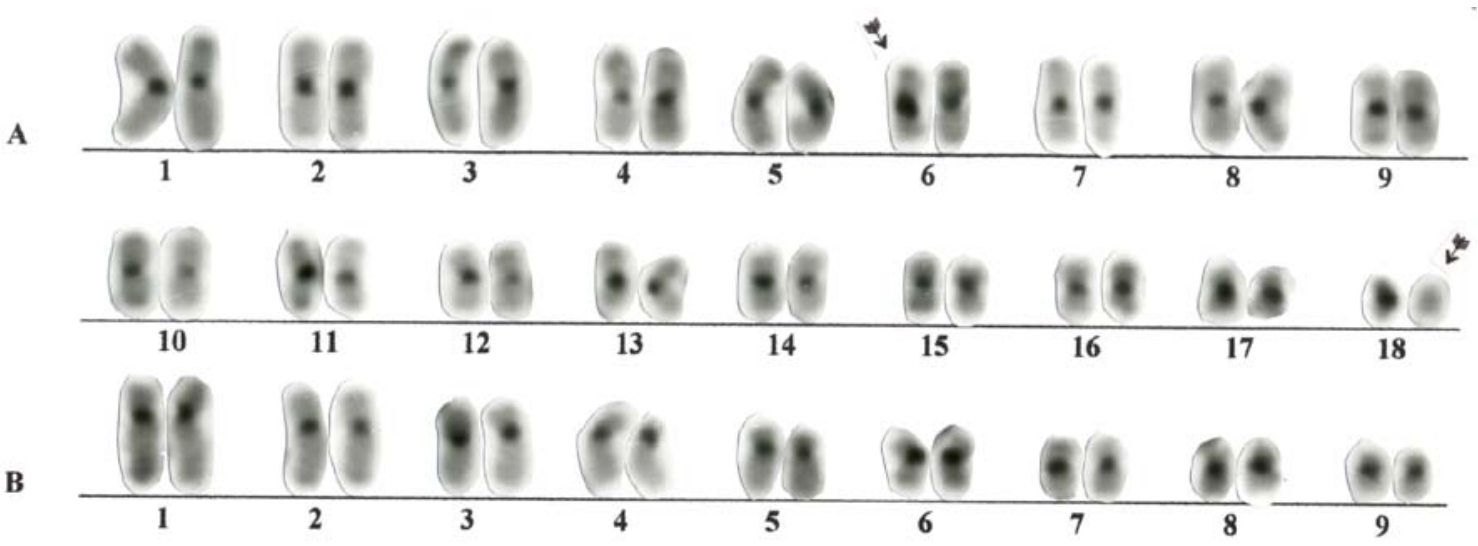

$\mathrm{C}$

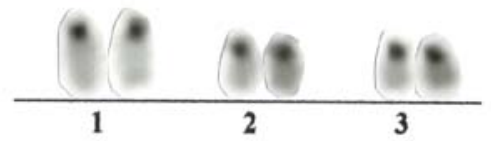

D
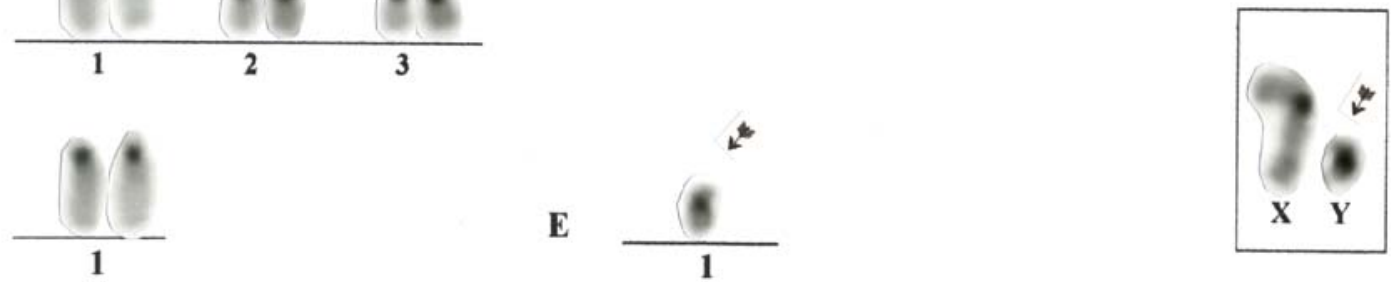

Fig. 5C

Fig. 5 - Banding $C(C B G)$ standard in the lineages $2 n=64$ and $2 n=65$. A) and C) the arrows point to one of the homologues from the pair A18, lacking the heterochromatical block (D. prymnolopha and Dasyprocta sp., respectively.); A), B) and C) one of the homologues from the pair A6 had an increasing of the heterochromatical block (D. prymnolopha, D. leporina and Dasyprocta sp., respectively); A) and C) the supernumerary chromosome with a constitutive heterochromatin in the pericentromeric region (D. prymnolopha and Dasyprocta sp., respectively). B) and C) the arrows point to the $\mathrm{Y}$ chromosome, almost totally heterochromatical (D. leporina and Dasyprocta sp., respectively).

of the analyzed cells showed one of the homologues with a secondary constriction and about $40 \%$ from the cells of both lineages present this morphology in two homologues. However, there is a necessity of a more detailed research to confirm this characteristic. The marking character of A18 chromosome of our samples was first described here. The remaining chromosome complement agrees with Lima (1993), Lima and Langguth $(1995,1998)$ researches in $D$. leporina and D. fuliginosa.

The X chromosome of the four species here studied is submetacentric, different from the one found in D. leporina and D. fuliginosa described as large metacentric (Kasahara and Yonenaga-Yassuda 1984, Lima and Langguth 1995, 1998). The Y chro- mosome of $D$. prymnolopha, D. leporina and Dasyprocta sp. is a small submetacentric, similar to the one described by $D$. variegata (Hungerford and Snyder 1964), but different from the described small metacentric chromosome of D. leporina (Kasahara and Yonenaga-Yassuda 1984, Lima 1993, Lima and Langguth 1995, 1998).

$\mathrm{G}$ banding comparison between species showed several chromosomes similarities (Figure 8), suggesting that these species are conserved at the chromosome level. This finding is similar to that found in four species of Ctenomys (C. flamarioni, C. mendocinus, $C$. porteousi and $C$. australis), in relation to 1, 2, 4-8, 11-14, 16, 18, 21 and 23 pairs (Freitas 1994), and in two species of Cavia (C. aperea and 
A
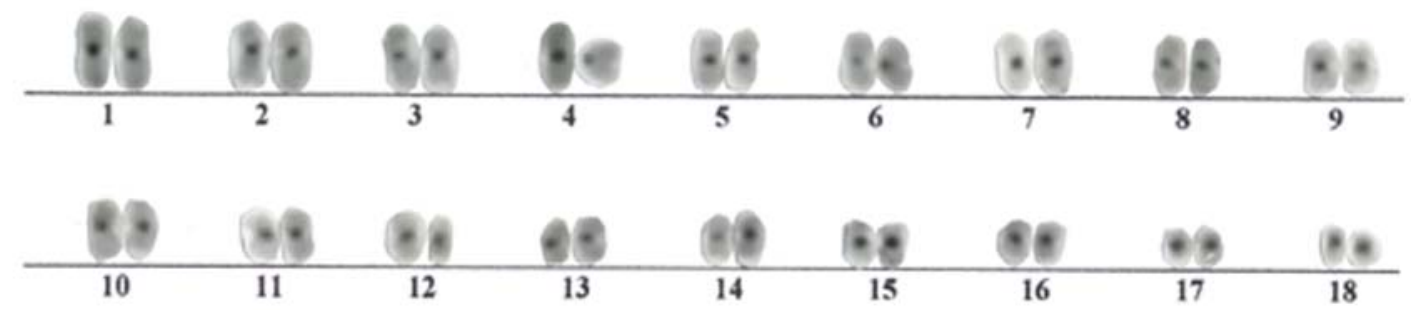

B

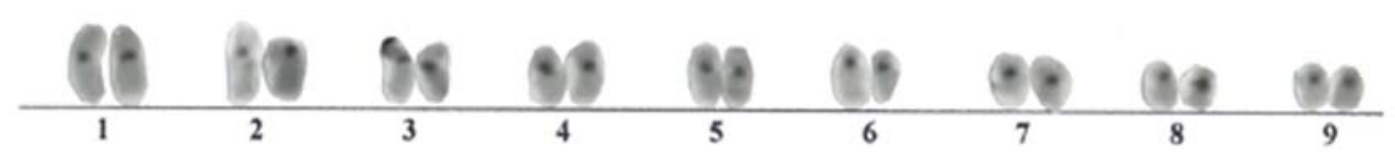

C

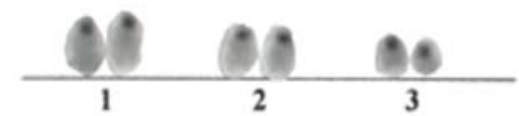

D
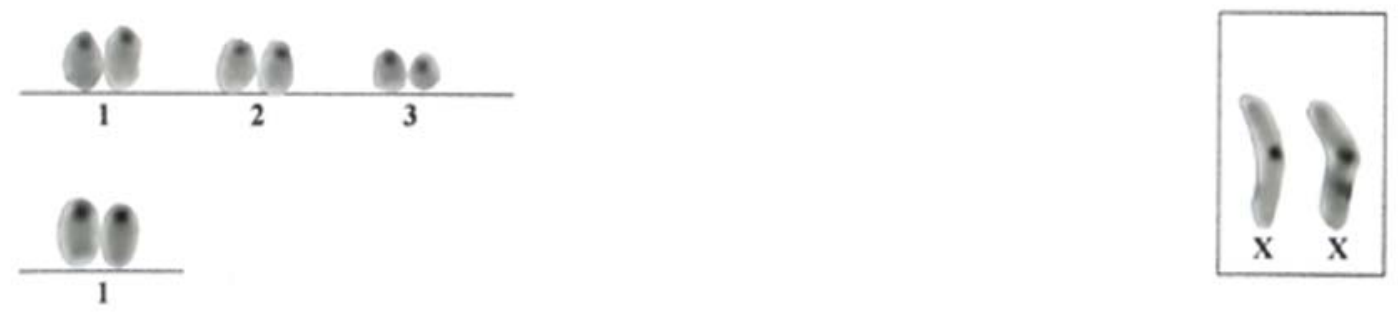

Fig. 6 - Banding C (CBG) standard of the lineage $2 \mathrm{n}=64$ of $D$. fuliginosa.

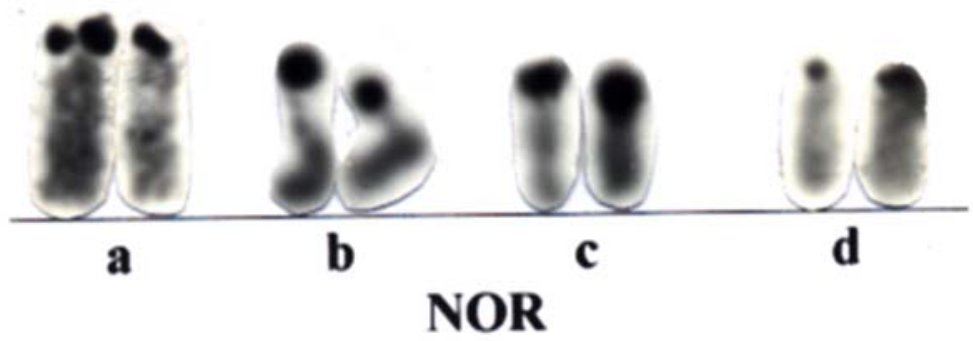

Fig. 7 - Localization of the Nucleolous Organizer Regions in the pair D1 in:

A) D. prymnolopha; B) D. leporina; C) D. fuliginosa; D) Dasyprocta sp.

C. aperea pamparum) that present similarity in the $\mathrm{G}$ banding standard in most of the autosomes (Maia 1984).

In spite of the difficulties in obtaining banded trypsin-Giemsa karyotypes of $D$. leporina and $D$. fuliginosa, we presented an idiogram (Figure 9) where we suggest the interpretation of positive (dark) and negative (clear ) bands distribution like an essay of $\mathrm{G}$ banding standard in Dasyprocta.

In $\mathrm{C}$ banding analysis, it was evident the pericentromeric constitutive heterochromatin is all chro- mosomes, including the supernumerary chromosome and $\mathrm{X}$ and $\mathrm{Y}$ sexual pair. This pattern is similar to the one found in other Hystricognathi as Cavia porcellus (Natarajan and Raposa 1974); Clyomys laticeps laticeps (Souza and Yonenaga-Yassuda 1982) and P. longicaudatus (Maia et al. 1988). D. leporina and Dasyprocta sp. presented the Y chromosome almost totally heterochromatic, as found in D. leporina (Lima 1993, Lima and Langguth 1995, 1998) and in some species from Ctenomys that presented Y chromosome varying from totally hete- 
D.p D.I D.spD.f.
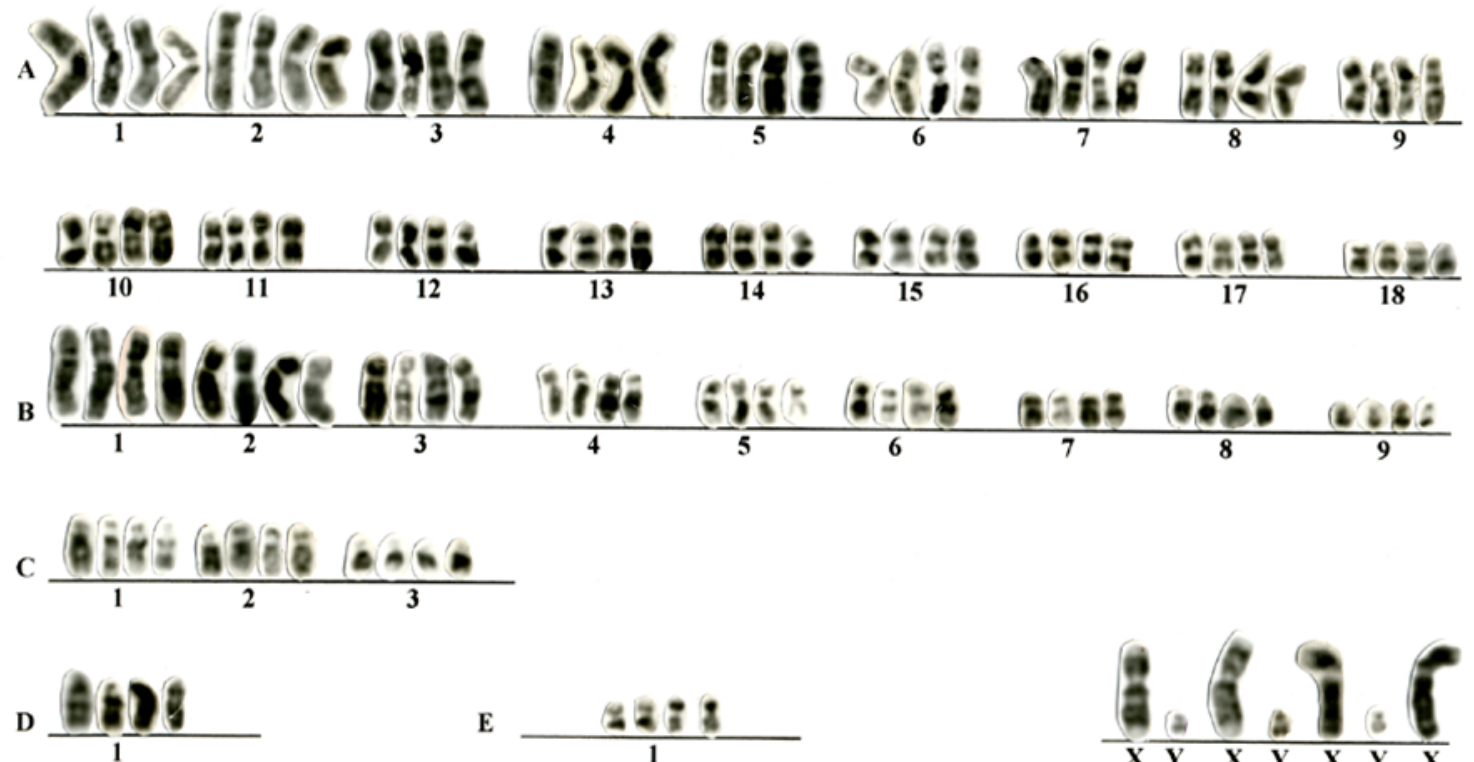

E

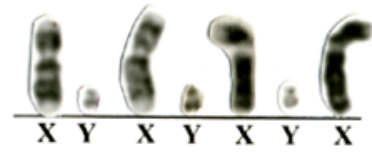

Fig. 8 - Comparisons of the banding standard G (GTG) in the four analized species. D.p - D. prymnolopha; D.1 - D. leporina; D.sp Dasyprocta sp.; D.f - D. fuliginosa.

rochromatic to $\mathrm{C}$ banding negative standard (Freitas 1994). D. prymnolopha, D. leporina and Dasyprocta sp. presented variation in the amount of heterochromatin in the A6 pair, similar to the observed by Reig et al. (1990) in the Ctenomyídeos (Hystricognathi). D. fuliginosa did not show variation in $\mathrm{C}$ banding and probably, this karyotype represents the basic standard of distribution and amount of constitutive heterochromatin in Dasyprocta.

In the four species the NORs were located in telomeric region of the short arm of both homologues of D1 pair, without size variation or NORs absence in any analyzed cell. This results are similar to the ones described in D. leporina and D. fuliginosa (Lima 1993).

\section{ACKNOWLEDGMENTS}

The authors thank Conselho Regional de Desenvolvimento Científico e Tecnológico (CNPq) for the financial support conceded and Museu Paraense Emílio Goeldi Zoobotanic Park and the vivarium of the Federal University of Pará for the donation of animals that built up our samples.

\section{RESUMO}

Foram estudados citogeneticamente um total de 30 animais das espécies D. prymnolopha $(\mathrm{N}=20)$, D. leporina $(\mathrm{N}=6)$, D. fuliginosa $(\mathrm{N}=1)$ e Dasyprocta sp. $(\mathrm{N}=3)$ (Dasyproctidae, Histricognathi). As preparações cromossômicas foram obtidas do cultivo de sangue periférico, além de medula óssea e baço em $D$. prymnolopha e $D$. leporina. O número diplóide foi de 64/65 em todos os exemplares. $\mathrm{O}$ cariótipo mostrou similaridade, não sendo detectado, através de coloração convencional de giemsa e de banda G, polimorfismo cromossômico em qualquer uma das espécies estudadas. A distribuição da heterocromatina constitutiva na região pericentromérica de todos os cromossomos foi similar nas quatro espécies. $D$. prymnolopha, D. leporina e Dasyprocta sp. apresentaram variação no tamanho do bloco heterocromático em um dos homólogos do par A18. D. fuliginosa apresentou a heterocromatina uniformemente distribuída em todos os 


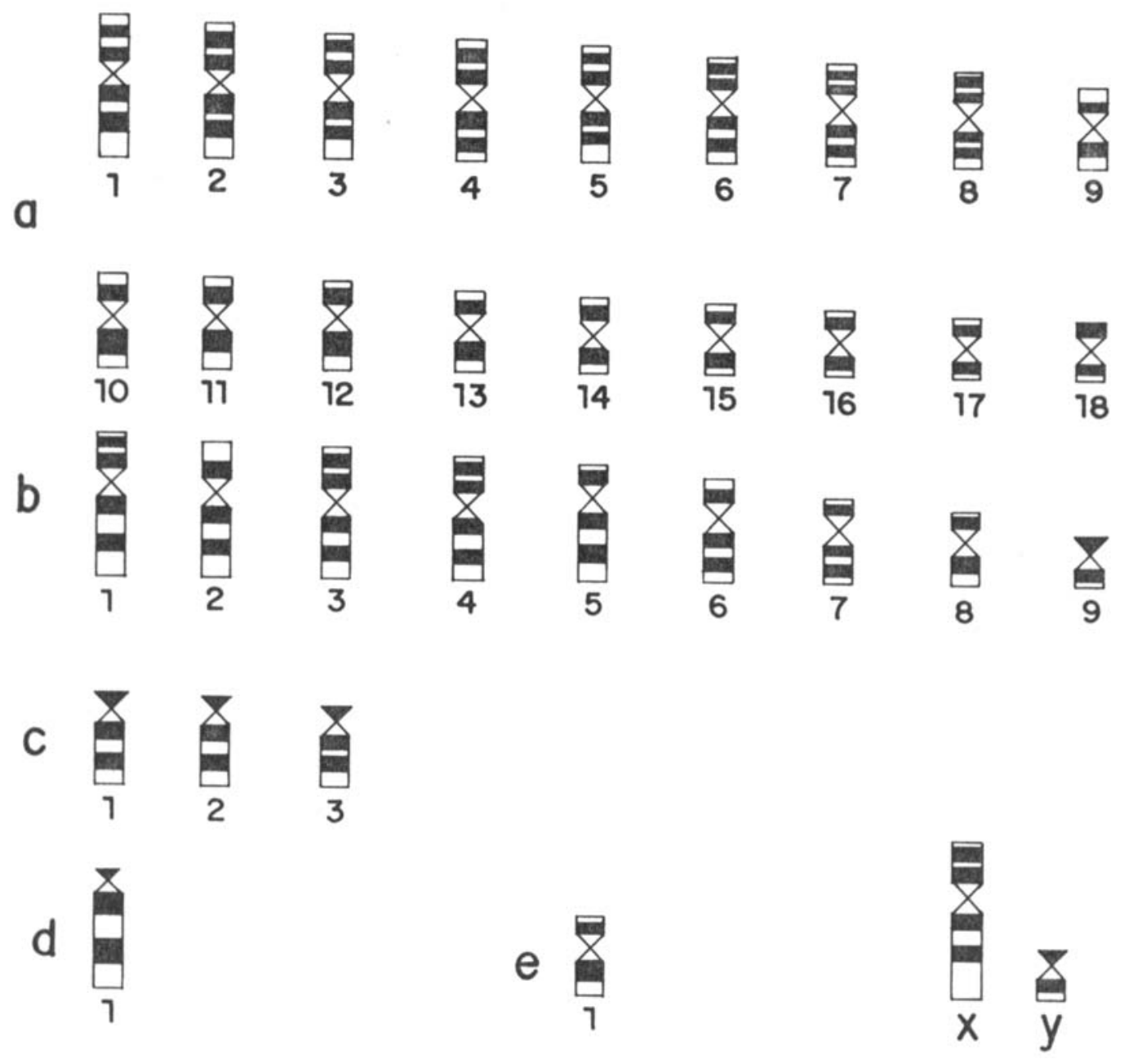

Fig. 9 - Idiogram presenting the banding G standards in D. prymnolopha, D. leporina, Dasyprocta sp. and D. fuliginosa, including the supernumerary chromosome (e1) of the last species.

cromossomos. Não houve variação no padrão das RONs entre as espécies estudadas.

Palavras-chave: Citogenética, Hystricognathi, Dasyprocta, Cariótipo.

\section{REFERENCES}

BAKer RJ, Haiduk MW, Robbins LW, CAdena A AND Koop BF. 1982. Chromosomal studies of South American bats and their systematic implications. In: M.A. Mares., H.H. Genoways (eds.) Mammalian Biology South America USA., p.303-306.

EISENBERG JF. 1989. Order Rodentia (Rodents, Roden- tia). In: Mammals of the Neotropics. Chicago: University of Chicago, p.329-418.

Emmons L. 1990. Large cavyalike rodents (Agoutidae, Dasyproctidae, Hydrochaeridae, Dynomyidae). In: Neotropical rainforest mammals. Chicago: University of Chicago, p. 203-212.

FAGUNDES V AND YASSUdA YY. 1995. Dois cariótipos de Trichomys aperoides (Echimyidae, Rodentia) com $2 n=26$ e $2 n=30$, investigados por hibridização "in situ" com sondas teloméricas. In: Congresso

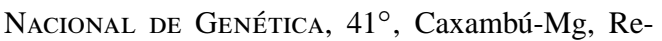
sumo...Seção C-155 18(3): 486.

Ford CE AND Hamerton JL. 1956. A colchicine hypo- 
tonic citrate squash sequence for mammalian chromosome. Stain Techn 31: 247-251.

Fredga K. 1966. Chromosome studies in five species of South American rodents (Suborder Hystricomorpha). Mamm Chrom News 20: 45-46.

FREITAS TRO. 1994. Geographical variation of heterochromatin in (Rodentia,Octodontidae) and its cytogenetics relationships with other species of the genus. Cytogenet Cell Genet 67: 193-198.

Gallardo M. 1991. Karyotypic evolution in Ctenomys (Rodentia, Ctenomyidae). J Mamm 72(1): 11-21.

Gallardo MH. 1992. Karyotypic evolution in octodontid rodents based on C-band analysis. J Mamm 73: 89-98.

George W And WeIR BJ. 1974. Hystrycomorph chromosomes. Symp Zool Soc Lond 34: 79-108.

Howell WM and Black DA. 1980. Controlled silverstaining of nucleolus organizer regions with a protective colloidal developer - - a 1-step method. Experientia 36: 1014-1015.

Hsu TC AND BenirschKe K. 1968. An atlas of mammalian chromosomes. New York: Springer-Verlag, 2: 72-76.

Hungerford DA AND SNyder RL. 1964. Karyotypes of two more mammals. Amer Natur 98: 125-127.

Kasahara S and Yonenaga-Yassuda Y. 1984. A progress report of cytogenetic data on brazilian rodents. Rev Bras Genet 7(3): 509-533.

LEAL-Mesquita ERRBP. 1991a. Estudos citogenéticos em dez espécies de roedores brasileiros da família Echimyidae. Dissertação de Mestrado. São Paulo, Universidade de São Paulo, 167p.

Leal-Mesquita ERRBP. 1991b. Cytogenetics studies of 10 species of brazilian rodent of the family Echimyidae. Rev Bras Genet 14: 1094.

LIMA JFS. 1993. Descrição de novos cariótipos em espécies de Sciuridae, Dasyproctidae e Erethizontidae com discussão da evolução cromossômica nos Caviomorpha,. Dissertação de Mestrado, Universidade Federal da Paraíba, 1993. 81p.
Lima JFS AND LANGGUTH A. 1995. Uma análise dos dados citogenéticos atuais dos Caviomorphos do Novo Mundo. In: Congresso Nacional de Genética, 41ํ․ 1995, Caxambú-Mg. Resumo... Seção C-162 18(3): 490.

Lima JFS AND LangGuth A. 1998. The karyotypes of three Brazilian species of the genus Dasyprocta (Rodentia:Dasyproctidae). Iher Ser Zool 85: 141145 .

Maia V. 1984. Karyotypes of three species of Caviinae (Rodentia, Caviidae). Experientia 40: 564-566.

Maia V, Langguth A and Almeida AB. 1988. Caracterização cromossômica do roedor equimídeo Proechimys cuvieri da região Amazônica (Rio Uatumã, AM). Cien Cult 40: 760.

Moorhead PS, Nowell PC, Nellman WJ, Battips DM AND Hungerford DA. 1960. Chromosome preparations of leukocytes cultured from human peripheral blood. Exp Cell Res 20: 613-616.

Moreira R, Garcia MRS, Lopes LD, SAntos CR AND LeAl-Mesquita ER. 1995. Análise cariotípica em Echimys chrysurus (Echimyidae, Rodentia). In: Congresso Nacional de Genética, $41^{\circ}$, Caxambú-Mg, Resumo..., Seção C-157 18(3): 487.

NATARAJAN AI AND RAPOSA I. 1974. Repetitive DNA and constitutive heterochromatin in the chromosomes of Guinea pig. Hereditas 76: 145-147.

Reig OA, Busch C, Ortells MO and Contreras JR. 1990. An overview of evolution. Systematics, population biology and speciation in Ctenomys. In: Nevo, E. AND ReIG, O.A. (eds.). Biology of Subterranean Mammals at the Organismal and Molecular Levels, New York, p. 71-96.

Seabright M. 1971. A rapid banding technique for human chromosome. Lancet: 971-972.

Souza MJ and Yonenaga-Yassuda Y. 1982. Chromosomal variability of sex chromosomes and NORs in Trichomys aperoides (Rodentia, Echimyidae). Cytogenet Cell Genet 33: 197-203.

Sumner AT. 1972. A simple technique for demonstrating centromeric heterochromatin. Exp Cell Res 75: 304306. 